\title{
7 innish Literature Meets Romanian Literature in Hungarian. The Case of the La Fontaine Literary Society
}

\section{Ildikó P. Varga}

Babeș-Bolyai University, Cluj-Napoca, E-mail: ildikovus@yahoo.com

\begin{abstract}
Rezumat

In this study, I examine how Finnish literature

In acest studiu, examinez modul în care literatura meets Romanian literature in the activities of a finlandeză se întâlnește cu literatura română în literary society based in Hungary, the La Fontaine Society. Using André Lefevere's concepts (literary system, rewriting, patronage, institutions, poetics, ideology, manipulation), I am looking for the answer to what motivated the selection of works for translation and publication.

My aim is to show and point out the factors that facilitate the meeting of two peripheral or small literatures, literary systems in a third language, which can also be considered peripheral and small - through translations.

activitățile unei societăți literare $c u$ sediul în Ungaria, Societatea La Fontaine. Folosind conceptele lui André Lefevere (sistem literar, rescriere, patronaj, instituții, poetică, ideologie, manipulare), caut răspunsul cu privire la ce a motivat selecția operelor pentru traducere și publicare.

Scopul meu este de a arăta și sublinia factorii care facilitează întâlnirea a două literaturi periferice sau mici, a două sisteme literare într-o a treia limbă, care, de asemenea, poate $f i$ considerată periferică și mică - prin traduceri.

Keywords: La Fontaine Literary Society; Béla Vikár; Finnish literature; Romanian literature; Hungarian literature; translations

CC BY-SA License (https://creativecommons.org/licenses/by-sa/2.0)

Acknowledgements: This paper has been presented at the 11th International Conference on Nordic and Baltic Studies in Romania: ReThinking Europe in Scandinavia and the Baltic Sea Region hosted by the Romanian Association for Baltic and Nordic Studies, online conference, May 28-29, 2020.
\end{abstract}

In the following, through the activities of the La Fontaine Literary Society, I present how Finnish and Romanian literatures meet in this Budapest-based literary society, and through this in Hungarian literary life.

I am looking for the answer to what motivated the selection of works for translation and publication. What role did the personal network of the members in a leading position play in the life of the society in terms of keeping certain literatures at the center or attracting new literatures? 
For my analysis, I use Béla Vikár's letters, as he is one of the founding members of the society, ${ }^{1}$ as well as the statutes of the society. ${ }^{2}$

\section{Theoretical framework}

In Even Zohar's Polysystem theory, literature is conceptualized as a dynamic, open system that is constantly connected to other systems (social, political, etc.). The dynamism of the systems stems from the hierarchical structure within the system, where virtually all actors aim to move from the periphery to the center. This is no different in literary systems, where the goal is to become canonized.

The literary systems of different nations come into contact with each other through translations. Even Zohar also distinguishes between central and peripheral systems of literature in the case of national literatures:

"Since peripheral literatures in the Western Hemisphere tend more often than not to be identical with the literatures of smaller nations, as unpalatable as this idea may seem to us, we have no choice but to admit that within a group of relatable national literatures, such as the literatures of Europe, hierarchical relations have been established since the very beginnings of these literatures." 3

Accepting this principle, I consider all three literary systems addressed in the analysis: Finnish, Romanian and Hungarian to be peripheral literatures within the European macro-polysystem. While Even Zohar examines the relationship between peripheral/small and central/large literary systems, the present case study focuses on the encounter of three small literatures.

In describing the role of the La Fontaine Society in one (or more) literary system(s), I use the concepts of André Lefevere. In his book entitled Translation, rewriting, and the manipulation of literary fame, Lefevere, drawing on Even Zohar's polysystem theory (as well), introduces concepts such as rewriting, patronage, institutions, poetics, ideology, manipulation in connection with the concept of Zohar's system.

\footnotetext{
1 Ildikó Varga P. (red., ed.), Vikár Béla levelei. (Cluj: Erdélyi Múzeum Egyesület), 2017.

${ }^{2}$ It can be found in Imre Bokor's Archives, MNL OL / National Archives of Hungary/ P 1748

${ }^{3}$ Itamar Even-Zohar: ‘Polysystem Studies.`Poetics Today 11. (1990/1) 48.
} 
Let's see what these mean and how they can be applied in our analysis.

Lefevere states in the introduction to his book that he considers translation to be a form of rewriting:

"Translation is, of course, a rewriting of an original text. All rewritings, whatever their intention, reflect a certain ideology and a poetics and as such manipulate literature to function in a given society in a given way. (...) Rewritings can introduce new concepts, new genres, new devices and the history of translation is the history also of literary innovation, of the shaping power of one culture upon another." ${ }^{4}$ - then he continues: "translation is the most obviously recognizable type of rewriting, and since it is potentially the most influential because it is able to project the image of an author and/or a (series of) work(s) in another culture, lifting that author and/or those works beyond the boundaries of their culture of origin..."

According to Lefevere, patronage "operates mostly outside the literary system" and means "something like the powers (persons, institutions) that can further or hinder the reading, writing, and rewriting of literature. It is important to understand "power « here in the Foucauldian sense, not just, or even primarily, as a repressive force."6

Although Lefevere mostly understands patronage as outside the literary system, his wording suggests that it may be part of it as well. In our case, the La Fontaine Society is just such an institution within the literary system, whose members are persons who represent the literary or political or economic elite/center. In Lefevere's view: “Patronage basically consists of three elements that can be seen to interact in various combinations. There is an ideological component (...). Needless to say, »ideology« is taken here in a sense not limited to the political sphere; (...) economic component: the patron sees to it that writers and rewriters are able to make a living (...), status component."7 The latter refers to the acceptance of patronage.

\footnotetext{
${ }^{4}$ André Lefevere, Translation, rewriting, and the manipulation of literary fame. London, New York: Routledge, 1992, vii.

${ }^{5}$ Ibid. 9.

${ }^{6}$ Ibid. 15.

${ }^{7}$ Ibid. 16-17.
} 
In the following, when I briefly present the activities of the La Fontaine Society, I will consider these terms.

\section{The La Fontaine Society}

The La Fontaine Literary Society was founded in Budapest in 1920 and operated until 1951.

The society was founded to publish La Fontaine's tales in Hungarian. One of the founding members, Béla Vikár, was one of the translators of the tales. Some of the tales were translated by Andor Kozma and Árpád Zempléni. In order to publish the tales, in January 1919 Vikár already turned to the Hungarian Academy of Sciences. One of the reasons for the publication of the translation was the 300th anniversary of the birth of Jean La Fontaine in the upcoming year of 1921.

The establishment of the society, however, was not limited to the intention to publish the translation volume. If we are looking for the ideological component that governs the operation of the society, then it is worth paying attention to the goals broadly defined in the statutes. Based on the statutes, the objectives of the society include the translation and introduction of the valuable works of world literature and Hungarian literature, as well as the presentation of these to the public at various literary evenings and matinees. What the society considered a valuable work is a more exciting question. Hereinafter, these aspects will be discussed: the ideological considerations behind the selection of works considered valuable.

This organisation defining itself as a society of world literature, unlike its name, is not only open to French culture, but it sought to cover European literature through its activities. Finnish literature, for example, occupied a central place in the events of the La Fontaine Society in the 1920s. ${ }^{8}$ The reason for this is that the founder, Béla Vikár, was well known as a translator of the Finnish epic, the Kalevala, in addition to La Fontaine tales.

8 Cf.: Ildikó P. Varga: 'Cultural policies. The first decade of the La Fontaine Literary Society (1920-1930).' Hungarian Studies 33. (2019/1): 103-114. DOI: 10.1556/044.2019.33.1.7 
In addition to Northern European literatures, the society's programs also include Dutch and Southern European literature. The central, major literatures - English and French - were regular guests at the society's meetings and reading evenings. German literature was the one missing. The reason for this is that the founders, together with German literature lovers, formed another society the main focus of which was specifically German literature: the Goethe Society. (This, of course, indicates the very important place of German literature in Hungarian literary life.)

In general, it can be said that European literatures were included mainly in the society's repertoire, and this is also relevant to our topic. However, it should be noted that non-European literatures - Arabic, Chinese and Japanese - were also occasionally given a spot.

\section{Literary society or more?}

Although the literature marker is officially included in the La Fontaine Society's name, its activity was more diverse. There is a reference to this in the last paragraph of its statutes, which reads as follows: "advocacy of all kinds of literature and art, distribution of theatrical, film and literary works, and promotion of their sale in the country and abroad."

Other arts represented themselves at literary evenings and matinees: usually professional actors read the translations, and singers performed. In December 1921, Dagmar Parmas ${ }^{9}$ sang Finnish songs, and Finlandia by Sibelius lightened one of the Northern (Swedish-Finnish) meeting. Dealing specifically with stage works characterized the society's first decade of activity.

The presence of other arts at the programs resulted in more publicfriendly events.

The society paid special attention to the delivery of literary texts to viewers/readers/listeners. That is why, it also made an attempt at book publishing. In the first decade of its operation, the translation by Aladár Bán of the Estonian epic, Kalevipoeg was published in 1929. The Hungarian translation was complete already in 1917. Vikár was asked to evaluate the

\footnotetext{
${ }_{9}^{9}$ Dagmar Parmas (1886-1940) Finnish singer, actress
} 
manuscript submitted to the Hungarian Academy of Sciences, who wrote a thorough analysis of the translation of several pages in which he compared the Hungarian text with the Estonian one.

Among the books published in the 1920s, we can also find the volume collecting La Fontaine's tales. As I have mentioned earlier, the primary objective of the society was to publish tales. However, they were first published by the Dante Publishing House with Vikár's preface and illustrations by Jenő Haranghy only in 1929, and then for the second time in 1942 with an introduction by János Hankiss.

The economic component, in fact, became so dominant by the 1930s that the number of books published by the La Fontaine Society, including those dealing with Finnish literature and culture, increased. In addition to the Kalevala, the society paid tribute to the 70-year-old Finnish composer Jean Sibelius with a volume. In 1938, the book Northern Light, a selection of Finnish lyric poetry, appeared.

Vasile Alecsandri's volume was also published in 1938 by the society, being translated by Árpád Bardócz.

How do the two literatures, Finnish and Romanian, meet in the life of the society? Would it be a coincidence, the result of a parallel interest within the society, or is there a common point where they meet along some similar ideology?

\section{Béla Vikár and his network}

Béla Vikár was always an advocate of the plans he called "big businesses". At the end of the 19th century, he was active in many similarly "big businesses": founding papers or organizing literature under less formal conditions. Although these plans were either never implemented or very short-lived for mainly material reasons, they proved to be useful for Vikár in terms of networking.

After retiring in July 1921, Vikár sought to take his share of the activities of the La Fontaine Society. Using his previous social network, he tried to involve more and more members in the life of the society. Among them we can find the prominent figures of Hungarian literature of the beginning of the 20th century, as well as foreign members who acted as 
external members of the society. The central position of the members increased the status and acceptance of the society within the Hungarian literary system.

Among the Finnish members of the society, we can mainly see people with whom Vikár already made contact at the end of the 19th century and at the turn of the century. To name a few, Eino Leino, Juhani Aho, Otto Manninen or Karle Krohn were at the forefront of contemporary Finnish intellectual life. But how did Vikár get in touch with these actors of Finnish cultural life?

Vikár began translating the Finnish epic, the Kalevala, in the 1880s. In 1889 he spent several months in Finland to improve his Finnish language competence. It was then that he became acquainted with leading figures of Finnish cultural life, and even became friends with several of them. The Kalevala translated by Vikár was first published in 1909. The second edition was published in 1935, on the 100th anniversary of the appearance of the Finnish Kalevala. After that, the epic appeared several times: in 1940, 1943 and 1944.

In the Hungarian reception of the Finnish epic, the decade between 1935 and 1945 represents the most productive years. ${ }^{10}$

The 1935 edition was read by a teacher, poet, translator and newspaper editor from Debrecen: Pál Gulyás (1899-1944).

\section{Gulyás and the Kalevala}

Pál Gulyás was one of the so-called folk writers. What exactly does this term cover? Primarily it is the opposite of the urban, those writers/poets considered themselves folksy who either came from a peasant background or showed a literary interest in the life of the peasantry or considered folk poetry as a relevant source of inspiration in the 20th century. Gulyás belonged to the latter. No wonder the Finnish epic had a great influence on him. He also used its motifs and stories in his poetry. In addition, in 1937 he wrote a study on the Kalevala, which appeared in the April issue of the journal entitled Válasz. As a result of the study, Gulyás

\footnotetext{
10 Cf.: Varga P. Ildikó: Hiisi szarvasától a csodaszarvasig. A Kalevala magyar fordításai. /From Hiisi`s Elk to the Wonderdeer./ (Cluj: Erdélyi Múzeum Egyesület, 2010.)
} 
came into contact with the translator of the Finnish epic, Béla Vikár. ${ }^{11}$ Their frequent correspondence ended with the sudden death of Gulyás in 1944.

The central theme of their correspondence was the Kalevala: the distribution and re-publishing of the work. In addition, La Fontaine Society events and various literary translations also had their space in the letters. Vikár's interest was so aroused by Gulyás' study of the Kalevala that he chose it as the introduction to the Kalevala published in 1943 and 1944 in Debrecen, entitling it Út a Kalevalához (Road to the Kalevala).

The poet and translator Gulyás was invited to join the La Fontaine Society after they initiated contact. Like all regular members, he had to deliver an inaugural speech. Gulyás gave his inaugural lecture on Romanian folk ballads on April 4, 1939 in the building of the Hungarian Academy of Sciences. Vikár knew about Gulyás' interest in folk ballads. They also mentioned this in their letters, and already at the reading meeting organized by the La Fontaine Society in April 1938, he asked for samples of the translation, as Gulyás published the translations of three Romanian folk ballads together with a study in September $1938 .{ }^{12} \mathrm{He}$ became acquainted with ballads through the volume by Constantin Brăiloiu. ${ }^{13}$ The Brăiloiu volume was of great interest among Gulyás' acquaintances. He also had to lend it to others, such as László Németh and Gábor Lükő. Based on this, Lükő also held a lecture at the Romanian folk music evening, which took place on March 25, 1939 in Budapest, at the Academy of Music. ${ }^{14}$

The meeting of Finnish and Romanian literatures here clearly takes place along poetics. In Lefevere's conceptualization: “Poetics can be said to consist of two components: one is an inventory of literary devices, genres, motifs, prototypical characters and situations, and symbols; the other concept of what the role of literature is, or should be, in the social system as a whole. The latter concept is influential in the selection of themes that

\footnotetext{
11 Béla Vikár's letters to Pál Gulyás, PIM /Petőfi Literary Museum, Archives/ V 4324/262/1-39

12 Pál Gulyás, ‘Három román népballada. Múfordítások bevezető tanulmánnyal.`Kelet Népe 1938/ september 166-177.

${ }^{13}$ Constantin Brăiloiu, ',Ale mortului” din Gorj', Muzică și poezie 1 (București, 1936.)

14 Cf.: Gulyás Klára - G. Merva Mária, ed. Egy barátság levelekben. Gulyás Pál és Németh László levelezése. (Petőfi irodalmi Múzeum, Budapest, 1990.)
} 
must be relevant to the social system if the work of literature is to be noticed at all."15

The placing of the Kalevala and the three Romanian folk ballads on one platform in the case of Vikár and Gulyás is connected with a common ideology, such as the interest in folk poetry, the introduction of folk poetry works from the periphery of the literary system to its center.

\section{The La Fontaine Society and Romanian literature}

Unlike Finnish literature, Romanian literature appeared quite late in the events of the La Fontaine Society, first on the evening of April 19, 1938. I think that the reason for this late publication is mostly to be found in the fact that the people who determined the life of the society did not have such a personal connection with Romanian literature as Vikár with the Finnish one or Imre Bokor, managing director of the society, with Dutch literature.

After all, one of the themes of the 1938 event was Vasile Alecsandri's poetry. The occasion for this was given by the fact that the volume entitled Könnycseppek (Teardrops), translated by Árpád Bardócz, was published by the society in this year. There were two lectures on the volume: Ferenc Kelecsényi and Béla Vikár also read out loud some of the translations.

Vasile Alecsandri (1821-1890) is a critical figure in the 19th century Romanian literature. In the 1850s, he was involved in the collection of Romanian folk ballads and published them in a revised version. ${ }^{16}$ The most famous one was the text entitled Mioriţa. Romanian folk poetry served as a source of inspiration for Alecsandri and also influenced his own/original poetry. ${ }^{17}$ One might think that Alecsandri's name also came to Vikár's attention through Gulyás. But this was not the case.

Romanian folk poetry was not far from Vikár, a collector of folk songs. As he did not speak Romanian, he could only become familiar with Romanian literature through Hungarian translations. Vikár was

\footnotetext{
${ }^{15}$ Lefevere 1992:26.

${ }^{16}$ Poezii poporale. Balade (Cîntice bătrânești) adunate și îndreptate de Vasile Alecsandri, Volumul I - Volumul II (Iasi, 1852-1853.)

17 Vasile Alecsandri, Doine și lăcrămioare 1842-1852 (Paris, 1853.)
} 
preoccupied with the issue and followed the Romanian literature translated into Hungarian. When Bardócz published the second volume of Alecsandri's poems in Cluj in 1935, ${ }^{18}$ Vikár greeted the volume with his own poem. ${ }^{19}$

When researching Vikár's letters, I found no sign that he had corresponded with Árpád Bardócz, but it is possible that letters were exchanged after the publication of the greeting poem.

I also found no trace in the materials of the La Fontaine Society of how exactly Alecsandri's volume came to the society's attention, who and why decided to publish this volume. We can therefore only rely on assumptions when we claim that it was Vikár who introduced the translator to the society and supported the publication of the translation volume in principle. However, our assumption is confirmed by the common ideology that also governs Vikár, Gulyás, and Bardócz when selecting literary works for translation. Whether the Finnish Kalevala, the Romanian folk ballads or Alecsandri's poetry, the interest in folk poetry, the modern folklore, clearly makes a link between the creators, their products and the literary systems of the source and target texts as well.

\section{Finnish and Romanian literature after 1945}

After Béla Vikár's death in September 1945, only Imre Bokor remained from the old management of the society, who continued to perform the duties of managing director.

Vikár's letters testify that he worked hard in the last months of his life to revive the society after the war. However, he did not live long enough to see that happen.

As for Romanian literature, meetings on the Romanian topic were held twice in 1950. At that time, in addition to the classics - Mihai Eminescu, George Coșbuc - contemporary authors such as Zaharia Stancu and Mihai Beniuc were also represented.

\footnotetext{
18 In the translation by Árpád Bardócz in 1926: Pasztellek (Pastels) and in 1935: Emlék (Memory).

19 Béla Vikár, Vendéglátó. Váci Hírlap 17th of July 1935. In addition to the poem, a sample from the volume was also published, Vasile Alecsandri: Vágy (Desire). Both poems are on the title page.
} 
However, Finnish literature is completely missing from the society's programs. The reason for this can be found in the fact that with Vikár's death the direct connection with Finnish literature was lost, in this sense there was no one to take Vikár's place.

However, if we examine the political change that took place in Hungary after the World War II and the relations between the two states Hungary and Finland - it seems that we have to look for a political ideology as well behind the lack of Finnish literature.

At the level of national literary policy, rapprochement with Finnish literature could only take place in 1950, when the Kalevala was republished under the foreword by Otto Kuusinen, President of the Karelian Soviet Socialist Republic. The Hungarian text faithfully followed the text edited by Kuusinen, published in Karelia in 1949, which appeared in Finnish and Russian, and which was organized around themes and genres, breaking down the structure of the Kalevala by Elias Lönnrot.

Romanian literature along the communist ideology was among the literatures that could be accepted in Hungary, while Finnish literature was not. Even in 1950, it only became accepted through Karelia, which was part of the Soviet Union. But the operations of the society were no longer affected by this. In 1951 it dissolved itself.

\section{Summary and conclusions}

French literature and culture played a prominent role in the La Fontaine Society's activity. This might seem to be natural when we consider that the name of the society includes the name La Fontaine or that French is a large, central literature in the European macro system.

Finnish and Romanian literatures, together with Hungarian, can be classified as small literatures. In my opinion, however, the weight and presence of a certain literature at the events were not determined by its position in the European literature, but rather by the network of regular members within the society. With the help of personal acquaintances, they were able to attract more creators and literatures. In order to do this, of course, there was a need for openness on the behalf of the society's administration and - why not - readership and audience. The interest of 
small literatures in one other is a less obvious operational policy even in the life of a world literary society. The fact that the encounter did take place was due to a common interest in maintaining personal networks and similar ideologies professed by the persons. In our case, the common interest in folk poetry.

If we are looking for an answer to the lessons that can be learned from the study of the activities of the La Fontaine Society, it is worthwhile to look further in comparing the activities of the society before and after 1945. After 1945, the place of the literature, as we have seen, was marked by the oppressive and censoring ideology of the political system. 


\section{References:}

\section{Archives:}

Imre Bokor's archives, MNL OL /National Archives of Hungary, Budapest/ P 1748

Béla Vikár’s letters to Pál Gulyás, PIM / Petőfi Literary Museum, Budapest, Archives/ V 4324/262/1-39

\section{Boooks and articles:}

Alecsandri, Vasile. Poezii poporale. Balade (Cîntice bătrânești) adunate și indreptate de Vasile Alecsandri, Volumul I (1852) - Volumul II (1853). Iasi.

Alecsandri, Vasile. Doine și lăcrămioare 1842-1852. Paris, 1853.

Alecsandri, Vasile. Pasztellek (transl. Árpád Bardócz). Cluj, 1926.

Alecsandri, Vasile: Emlék (transl. Árpád Bardócz). Cluj: Erdélyi Szépmíves Céh, 1935.

Alecsandri, Vasile. Könnycseppek (ford. Árpád Bardócz). La Fontaine Társaság, Budapest, 1938.

Brăiloiu, Constantin. '„Ale mortului” din Gorj', Muzică și poezie 1, București, 1936.

Even-Zohar, Itamar. 'Polysystem Studies. ’ Poetics Today 11. (1990/1)

Gulyás Klára - G. Merva Mária. ed. Egy barátság levelekben. Gulyás Pál és Németh László levelezése. Petőfi Irodalmi Múzeum, Budapest, 1990.

Gulyás Pál. 'Három román népballada. Müfordítások bevezetô tanulmánnyal.' Kelet Népe 1938/september 166-177.

Lefevere, André. Translation, rewriting, and the manipulation of literary fame. London, New York: Routledge, 1992.

Varga P. Ildikó. Hiisi szarvasától a csodaszarvasig. A Kalevala magyar fordításai. /From Hiisi's Elk to the Wonderdeer./ Cluj: Erdélyi Múzeum Egyesület, 2010.

Varga P. Ildikó. Vikár Béla levelei. „Finnország egyik leglelkesebb diplomatája itt több mint 50 éven keresztül”. Cluj: Erdélyi Múzeum Egyesület, 2017.

Varga P. Ildikó: Cultural policies. The first decade of the La Fontaine Literary Society (1920-1930). Hungarian Studies 33. (2019/1) 103-114. DOI: 10.1556/044.2019.33.1.7 